\title{
Minat Mahasiswa Melanjutkan Kuliah: Intensitas Promosi, Kepercayaan dan Biaya Kuliah
}

\author{
Student Interest Continues College: Promotion Intensity, Trust and \\ Tuition Costs
}

Oleh:

\author{
Trias Fafirudin ${ }^{1}$; Fitriani ${ }^{2}$; Anna Wulandari ${ }^{3}$ \\ Program Studi Magister Manajemen, Universitas Pelita Bangsa \\ trias.fafirudin@pelitabangsa.ac.idi'ulfafitriani1798@gmail.com²; anna.wulandari@pelitabangsa.ac.id
}

Publish: 31 Dec 2021

\begin{abstract}
ABSTRAK
Tujuan penelitian untuk menguji model penelitian yang menyatakan bahwa intensitas promosi, biaya kuliah mempengaruhi minat mahasiswa melanjutkan kuliah serta kepecayaan sebagai penghubung intensitas promosi. Metode penelitian ini menggunakan pendekatan kuantitatif, dengan sampel penelitian alumni mahasiswa sekitar kab. Bekasi menggunakan penyebaran kuesioner google form secara online. Analisis penelitian yang digunakan adalah model struktural diolah software SMARTPLS 3.0. Penelitian menunjukkan bahwa kepercayaan tidak dapat menjadi penghubung antara intensitas promosi dan minat kuliah. Serta biaya kuliah berpengaruh positif terhadap minat kuliah.

Kata Kunci: Intensitas Promosi; Kepercayaan; Biaya Kuliah; Minat Kuliah
\end{abstract}

\begin{abstract}
The purpose of the study was to examine the model which states that promotion intensity, tuition fees affect student interest in continuing their studies and trust as a link to promotion intensity. This research method uses a quantitative approach, with a research sample of alumni students around the district. Bekasi uses an online google form questionnaire. The research analysis used is structural software that is processed by SMART-PLS 3.0. Research shows that trust cannot be a link between promotion intensity and college interest. And tuition fees have a positive effect on interest in college.

Keywords: Promotion Intensity; Trust; Tuition costs; Study Interest
\end{abstract}

\section{PENDAHULUAN}

Era Pandemi kini ini sangat berdampak pada perekonomian di Indonesia. Banyak perusahaan tutup sebab kerugian yang begitu besar serta tidak mampu buat bangkit dampak pandemi covid-19. Kemenaker menjelaskan terdapat kurang lebih 29,4 juta orang terdampak dampak wabah ini, termasuk baik buat mereka yang terkena PHK, dirumahkan tanpa upah juga dikurangi jam kerjanya (tribunnews, 2021). Kondisi seperti ini juga berdampak pada dunia Pendidikan dimana pada tahun 2020 Kemendikbud mengeluarkan surat perintah bahwa pembelajaran dilakukan dengan meniadakan tatap muka selama pandemic diseluruh instansi pendidikan untuk meminimalisir penularan covid-19.

Pembelajaran jarak jauh hampir dua tahun dilakukan instansi pendidikan seperti kampus Universitas Pelita Bangsa. Pembelajaran daring dapat dijadikan solusi pembelajaran jarak jauh ketika 
terjadi bencana alam. Seperti yang terjadi saat ini ketika pemerintah menetapkan kebijakan social distancing.

Social distancing diterapkan oleh pemerintah dalam rangka membatasi interaksi manusia dan menghindarkan masyarakat dari kerumunan agar terhindar dari penyebaran virus COVID19. Hal ini dapat berdampak buruk pada minat masyarakat untuk melanjutkan pendidikan yang lebih tinggi di kampus universitas pelita bangsa.

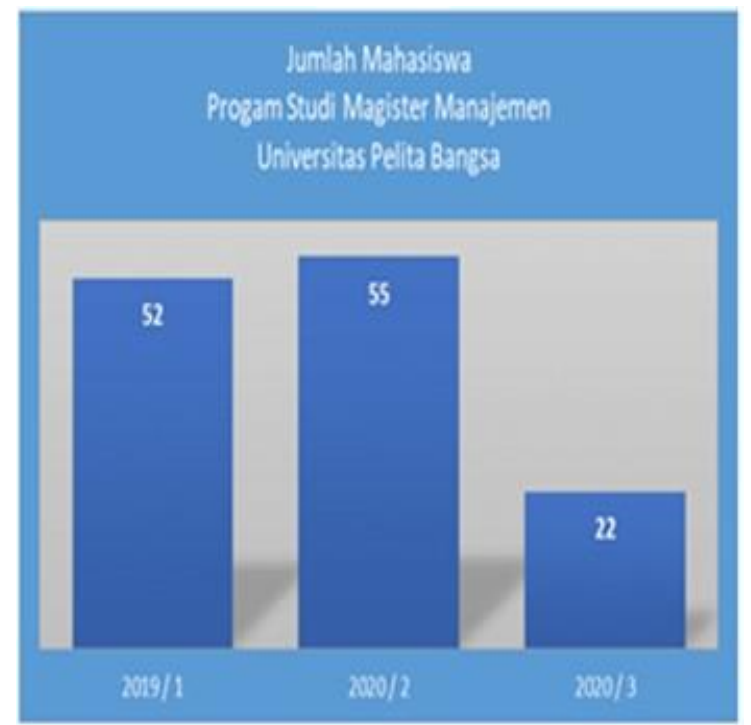

Sumber: ecampus.pelitabangsa.ac.id

Gambar 1. Data Statistik Penerimaan Mahasiswa Baru Universitas Pelita Bangsa

Gambar 1 menunjukkan, adanya jumlah penurunan minat kuliah selama pandemi. Hal ini membuat pimpinan UPB memerintahkan dalam mempromosikan kuliah di kampus Universitas Pelita Bangsa dengan semenarik mungkin.

Promosi yang dilakukan sebuah organisasi cenderung meningkatkan minat konsumen (Setyowati, 2015). Namun, terdapat temuan penelitian yang berbeda (Kamila, 2018) yang menunjukkan tidak adanya pengaruh promosi pada minat kuliah.

Perbedaan hasil penelitian tersebut terjadi karena promosi yang dimaksud belum terarah. Oleh karena itu pada penelitian ini, promosi diukur secara lebih spesifik yaitu intensitas promosi. Selain itu, intensitas promosi tidak serta merta mendorong ketertarikan mahasiswa untuk melanjutkan kuliah sehingga ditambahkan kepercayaan sebagai penghubung. Pesan menarik yang disampaikan lebih sering melalui promosi dapat mendorong keyakinan calon konsumen bahwa organisasi tersebut akan memenuhi harapan konsumen (Wijayanto, Rahadhini, \& Sumaryanto, 2018).

Surat perintah dari pemerintah untuk melakukkan social distancing. Hal ini dapat menyebabkan adanya keterbatasan dalam melakukkan promosi kunjungan kesekolah, perusahaan maupun masyarakat sekitar. Salah satu solusinya yaitu promosi di media sosial, zaman era teknologi saat ini semua orang pasti cenderung beraktivitas di media sosial.

Namun terdapat kendala lainnya yang bisa mempengaruhi minat kuliah dimasa pandemi salah satunya yaitu biaya. Akibat dari pandemic banyak orang yang kehilangan pekerjaan, ada pula yang ingin bekerja langsung untuk memenuhi kebutuhan hidup. Namun, terdapat penelitian yang menyatakan bahwa biaya tidak memiliki pengaruh terhadap minat kuliah (Fajarsari, 2020). Berbeda dengan penelitian yang dilakukkan oleh (Syaifulloh, Wahana, \& Riono, 2020) mengungkapkan bahwa biaya memiliki pengaruh positif terhadap minat kuliah. Ada pula bahwa biaya memiliki pengaruh negative terhadap minat kuliah (Berlinasari \& Erawati, 2017). Dapat disimpulkan dengan biaya yang terjangkau dapat menarik minat kuliah semakin tinggi akan tetapi jika biaya mahal dapat menyebabkan minat kuliah menurun terutama di masa pandemic.

Kepercayaan timbul dengan adanya promosi yang gencar dilakukan mendorong ketertarikan untuk melanjutkan pendidikan yang lebih tinggi. Semakin tinggi keyakinan dapat membantu mengembangkan potensi diri dalam melanjutkan ke perguruan tinggi. Seperti penelitian sebelumnya (Tilaar, Lapian, \& Roring, 2018) menyatakan bahwa dengan kepercayaan dapat berpengaruh positif terhadap minat. 
Adanya ketidaksamaan dalam hasil penelitian yang dijabarkan mendorong untuk melakukan penelitian lebih lanjut dalam memperjelas pengaruh promosi terhadap minat kuliah dengan menambahkan kepercayaan sebagai variabel intervening.

Penelitian minat kuliah memiliki daya tarik tersendiri, apalagi dimasa pandemi saat ini banyak hal yang harus dipertimbangkan bagi masyarakat sekitar dalam melanjutkan jenjang pendidikan yang lebih tinggi. Ditambah dengan berlakunya surat perintah dari pemerintah dalam mencegah penularan virus covid-19 adanya pembatasan mobilitas sehingga adanya hambatan kegiatan promosi penerimaan mahasiswa baru. Penelitian ini memasukkan variabel intervening yakni kepercayaan. Sehingga masyarakat persepsi bahwa dengan promosi yang sangat menarik membuat masyarakat memiliki kepercayaan apalagi jika biaya yang ditawarkan terjangkau dengan begitu kepercayaan masyarakat pada minat kuliah semakin meningkat.

\section{METODE PENELITIAN}

\section{Pengembangan Model}

\section{Intensitas Promosi dan Kepercayaan}

Intensitas promosi merupakan suatu tindakan promosi yang dilakukan oleh perusahaan atau organisasi secara terusmenerus dengan maksud mencapai keyakinan konsumen secara optimal. Penggunaan intensitas promosi seperti mengiklankan program pendidikan di berbagai media, adanya discount, mensponsori kegiatan mahasiswa, serta personal selling yang dilakukan maka dapat meningkatkan kepercayaan konsumen (Wahyono \& Susilawati, 2016). H1: Intensitas promosi berpengaruh positif terhadap kepercayaan

\section{Biaya Kuliah dan Minat Lanjut Kuliah}

Biaya Kuliah merupakan suatu

kewajiban finansial yang harus dikeluarkan oleh konsumen dalam menempuh pendidikan tinggi. Biaya kuliah menjadi salah satu faktor yang harus dipertimbangkan oleh konsumen. Sebagian konsumen biaya kuliah yang besar tidak menjadi masalah asalkan dapat diterima di perguruan tinggi yang berkualitas. Namun terdapat konsumen yang kondisi ekonominya terbatas, apalagi dimasa pandemic saat ini. Biaya kuliah merupakan faktor esensial dan tidak dapat dipisahkan dalam proses belajar mengajar (Syaifulloh, Wahana, \& Riono, 2020). Melanjutkan pendidikan yang lebih tinggi dapat mendorong potensi sumber daya manusia lebih berkualitas, maka diperlukannya suatu kebijakan yang harus dilakukan agar minat kuliah pada masyarakat meningkat yaitu pembayaran pekuliahan yang dapat diangsur dan terjangkau. Sehingga masyarakat dapat memiliki kemauan untuk melanjutkan pendidikan yang lebih tinggi. (Setyowati, 2015).

H2: biaya kuliah berpengaruh positif terhadap minat kuliah

\section{Kepercayaan dan Minat Kuliah}

Kepercayaan konsumen sangat penting dalam meningkatkan minat melanjutkan studi yang lebih tinggi. Konsumen akan berminat kuliah jika adanya citra positif institusi, fasilitas yang memadai, serta mampu menjaga kualitas program yang dimiliki. Apabila UPB dapat dipercaya maka konsumen dapat merekomendasikan kepada konsumen lainnya, akan tetapi jika UPB tidak mampu mempertahankan citra positif dan kualitas program pendidikan maka konsumen tidak akan merekomendasikan ataupun melanjutkan kuliah. Rasa percaya yang terbentuk dari konsumen pada UPB akan tergerak untuk minat kuliah (Tilaar, Lapian, \& Roring, 2018).

H3: Kepercayaan berpengaruh positif terhadap minat kuliah

\section{Desain Penelitian}

Meningkatkan Jumlah Mahasiswa memerlukan suatu tindakan intensitas promosi dan biaya kuliah yang terjangkau. 
Intensitas pormosi yang dilakukan dapat mempengaruhi rasa kepercayaan konsumen, serta biaya kuliah yang ditawarkan sehingga melanjutkan untuk studi lanjut.

\section{Pengumpulan Data}

Teknik pengumpulan data dengan melakukkan observasi penyebaran kuesioner menggunakan google form secara online. Dengan populasi penelitian yaitu Alumni Mahasiswa Sarjana Strata Satu baik dari perguruan tinggi negeri maupun perguruan tinggi swasta terutama diwilayah Kabupaten Bekasi.

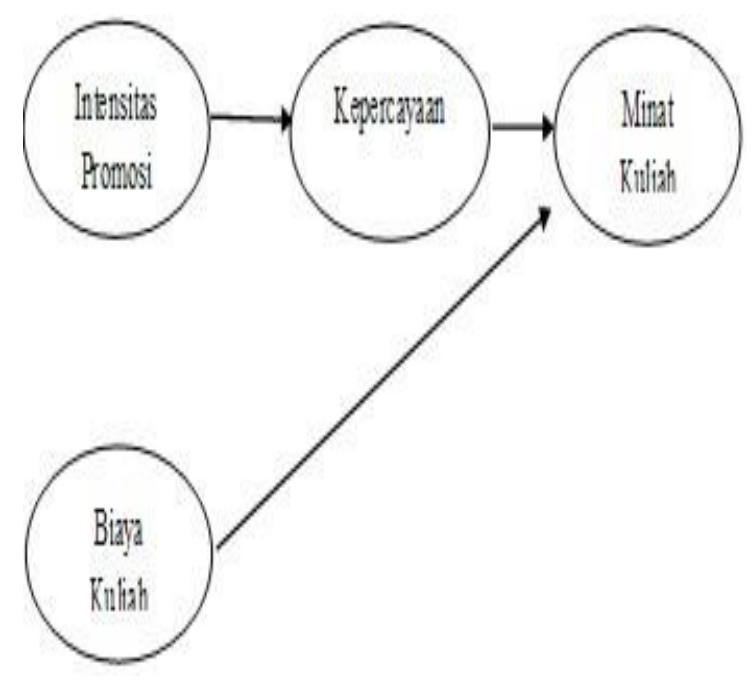

Gambar 2. Model Penelitian

Tabel 1. Variabel Penelitian

\begin{tabular}{|c|c|c|}
\hline Variabel & Indikator & Skala \\
\hline $\begin{array}{l}\text { Intensitas Promosi } \\
\text { (Wahyono \& } \\
\text { Susilawati, 2016) }\end{array}$ & $\begin{array}{l}\text { Sering iklan } \\
\text { Sering memberikan discount } \\
\text { Sering mensponsori kegiatan } \\
\text { Humas Aktif memberikan penjelasan }\end{array}$ & $1-5$ \\
\hline $\begin{array}{l}\text { Biaya Kuliah (X2) } \\
\text { (Setyowati, 2015) }\end{array}$ & $\begin{array}{l}\text { Biaya pendidikan murah. } \\
\text { Pembayaran fleksibel } \\
\text { Pendaftaran Murah } \\
\text { Per Semester murah }\end{array}$ & $1-5$ \\
\hline $\begin{array}{l}\text { Kepercayaan }(Z) \\
\text { (Tilaar, Lapian, \& } \\
\text { Roring, 2018) }\end{array}$ & $\begin{array}{l}\text { Yakin menjaga Kualitas } \\
\text { Yakin mempertahankan Citra } \\
\text { Yakin menyediakan Fasilitas. } \\
\text { Yakin memiliki Program berkualitas. }\end{array}$ & $1-5$ \\
\hline $\begin{array}{l}\text { Minat Kuliah (Y) } \\
(\text { Kamila, 2018) }\end{array}$ & $\begin{array}{l}\text { Aktif Mencari Informasi } \\
\text { Tergerak untuk mendaftar } \\
\text { Tertarik mengikuti Program } \\
\text { Memiliki hasrat studi lanjut }\end{array}$ & $1-5$ \\
\hline
\end{tabular}

\section{Metode Analisis}

Metode analisis dengan pendekatan kuantitatif. Langkah analisis meliputi pengujian outer dan inner model. Pengujian outer menggunakan loading outer sebagai bentuk uji validitas dengan cut off $>0,7$ tetapi masih tetap dipertahankan jika nilai loadings outer tidak kurang dari 0,4. Cronbach's Alpha dengan cut off $>0,7$ dan nilai $\rho c$ (composite reliability) dengan cut off $>0,8$ digunakan untuk pengujian Reliabilitas. Pengujian inner model sebagai model structural menggunakan R2 dan Estimasi koefisien. Cut off untuk variabel laten endogenous R2> 0,2. Untuk memvalidasi secara keseluruhan model menggunakan Goodness of Fit (GOF) dengan nilai NFI cut off $>0,1$. Pengujian hubungan jalur dalam model structural menggunakan standar estimasi dengan cut off $p$-value $<0,05$. 
Tabel 2. Responden

\begin{tabular}{lcc}
\hline Karakteristik & Jumlah & Persen \\
\hline Jenis Kelamin & & \\
- Perempuan & 16 & $33.3 \%$ \\
- Laki-Laki & 32 & $66.7 \%$ \\
\hline Usia & & \\
- 21-30 tahun & 33 & $68.8 \%$ \\
- 31-40 tahun & 11 & $22.9 \%$ \\
- 41-50 tahun & 5 & $10.4 \%$ \\
\hline Asal Perguruan Tinggi & & \\
Perguruan Tinggi Swasta & 42 & $87.5 \%$ \\
Perguruan Tinggi Negeri & 6 & $12.5 \%$ \\
\hline
\end{tabular}

Tabel 3. Outer Model

\begin{tabular}{|c|c|c|c|}
\hline Variabel/Indikator & $\begin{array}{l}\text { Outer } \\
\text { Loading }\end{array}$ & $\begin{array}{c}\text { Cronbah's } \\
\text { Alpha }\end{array}$ & $\begin{array}{l}\text { Composite } \\
\text { Reliability }\end{array}$ \\
\hline Intensitas Promosi & & 0.798 & 0.869 \\
\hline - Sering iklan & 0.850 & & \\
\hline - Sering memberikan discount & 0.693 & & \\
\hline - Sering mensponsori kegiatan & 0.798 & & \\
\hline - Humas Aktif & 0.815 & & \\
\hline Biaya Kuliah & & 0.859 & 0.903 \\
\hline - Biaya pendidikan murah & 0.918 & & \\
\hline - Pembayaran fleksibel & 0.733 & & \\
\hline - $\quad$ Biaya Pendaftaran murah. & 0.821 & & \\
\hline - $\quad$ Biaya Per Semester murah & 0.865 & & \\
\hline Kepercayaan & & 0.825 & 0.884 \\
\hline - Yakin menjaga Kualitas & 0.848 & & \\
\hline - Yakin mempertahankan Citra & 0.692 & & \\
\hline - $\quad$ Yakin Fasilitas yang Memadai. & 0.843 & & \\
\hline - Yakin Program berkualitas. & 0.846 & & \\
\hline Minat Kuliah & & 0.884 & 0.921 \\
\hline - Aktif Mencari Informasi & 0.772 & & \\
\hline - $\quad$-Tergerak mendaftar & 0.881 & & \\
\hline - - Tertarik mengikuti Program & 0.883 & & \\
\hline - $\quad$-Memiliki hasrat studi lanjut & 0.908 & & \\
\hline
\end{tabular}

Sumber: Hasil Pengolahan, 2021 


\section{HASIL PENELITIAN}

Responden penelitian yakni 48 orang yang sebagian besar laki-laki, usia diatas 21 tahun dan berasal dari pendidikan perguruan tinggi swasta. Pengujian outer yang digunakan untuk pengujian validitas dan realibilitas hampir semua seluruh indikator pada setiap variabel telah valid namun terdapat dua indikator memiliki nilai loading outer 0,692 dan 0,686 akan tetapi tetap dipertahankan karena tidak berada dibawah 0,4 . Seluruh variabel juga telah reliabel karena telah memenuhi cut off yang digunakan pada penelitian ini. Cronbach alpha Intensitas promosi 0,798; Biaya Kuliah 0,859; Kepercayaan 0,825; Minat Kuliah 0,908 lebih besaar dari 0,7. Sedangkan untuk composite reliability Intensitas promosi 0,869; Biaya Kuliah 0,903; Kepercayaan 0,883; Minat Kuliah 0,936 lebih besar dari 0,8 .

Model dapat diterima karena seluruh variabel endogen memiliki nilai $R$ square diatas 0,2. Variabel endogen kepercayaan memiliki nilai $\mathrm{R}$ square sebesar 0,303 atau masuk dalam kriteria moderat, variabel endogen minat kuliah bernilai $\mathrm{R}$ square sebesara 0,247 termasuk dalam kategori moderat. Model dapat diterima hasil NFI menunjukkan diatas 0,1 dapat dikatakan model jauh lebih baik.

Estimasi pengujian dari indikator ke variabel keterkaitan dengan antar variabel. Seluruh indikator telah berkontribusi membentuk masing-masing variabel. Indikator X1.1 merupakan indikator utama pembentuk intensitas promosi, X2.1 indikator utama biaya kuliah, Z1 indikator utama kepercayaan dan Y4 merupakan indikator utama minat kuliah.

Gambar 2 menunjukkan: 1) Intensitas signifikan terhadap kepercayaan, 2) Biaya kuliah signifikan pada minat kuliah, 3) Kepercayaan tidak signifikan terhadap minat kuliah. Informasi lainnya didapat yaitu kepercayaan tidak signifikan menjadi penghubung antara intensitas promosi dengan minat kuliah.

Tabel 4. NFI 2021

\begin{tabular}{lcr}
\hline & Model Saturated & Model Estimasi \\
\hline SRMR & 0,095 & 0,121 \\
d_ULS & 1,239 & 2,002 \\
d_G & 0,770 & 0,813 \\
Chi-Square & 186,228 & 189,936 \\
NFI & 0,648 & 0,641 \\
\hline
\end{tabular}

Sumber: Hasil Pengolahan, 2021

Tabel 5. Estimasi

\begin{tabular}{llccl}
\hline Alur & Jenis & $\begin{array}{l}\text { Std. } \\
\text { Estimasi }\end{array}$ & P-Value & Kesimpulan \\
\hline Intensitas Promosi $\rightarrow$ Kepercayaan & Langsung & 0.551 & 0.000 & Signifikan \\
Biaya Kuliah $\rightarrow$ Minat Kuliah & Langsung & 0.323 & 0.050 & Signifikan \\
Kepercayaan $\rightarrow$ Minat Kuliah & Langsung & 0.264 & 0.137 & Tidak \\
& & & & Signifikan \\
$\begin{array}{l}\text { Intensitas Promosi } \rightarrow \text { Kepercayaan } \rightarrow \\
\text { Minat Kuliah }\end{array}$ & Tidak & 0.145 & 0.170 & Tidak \\
\hline
\end{tabular}




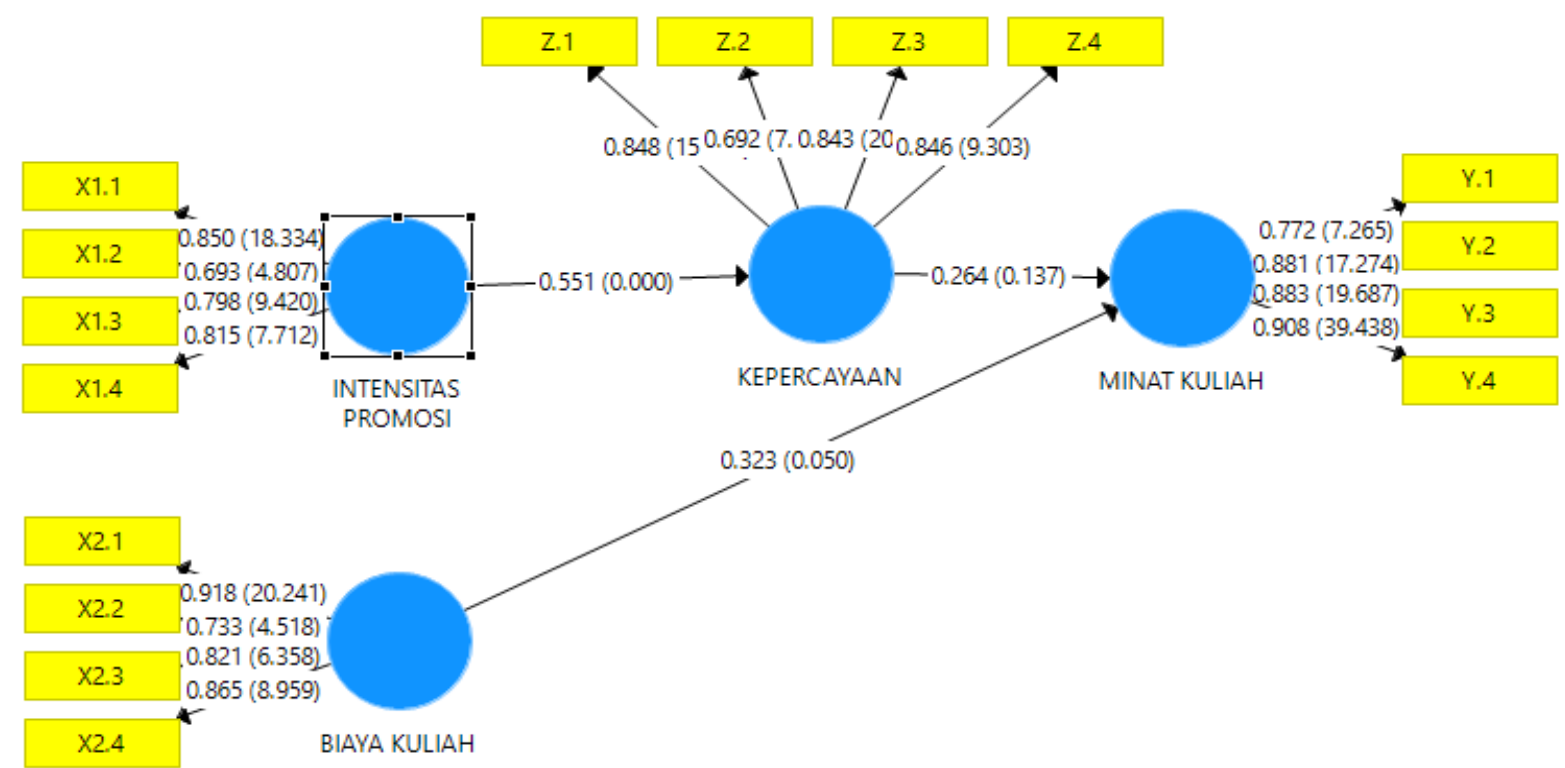

Gambar 2. Model

\section{PEMBAHASAN}

\section{Intensitas promosi terhadap kepercayaan}

Semakin menarik dan mengiklankan program pendidikan yang berkualitas serta adanya discount yang diberikan, sehingga konsumen yakin bahwa universitas pelita bangsa dapat menjaga kualitas pendidikan yang dimiliki. Kemampuan kampus dengan mensponsori kegiatan mahasiswa, serta menjaga citra positifnya maka masyarakat semakin percaya dengan kualitas pendidikan yang dimiliki.

Hasil penelitian ini sejalan dengan penelitian yang dilakukan (Wahyono \& Susilawati, 2016); (Huang, Brink, \& Groot, 2011) dengan melakukan intensitas promosi yang sering dan menarik dapat mempengaruhi kepercayaan masyarakat.

\section{Biaya Kuliah terhadap minat kuliah}

Biaya kuliah yang dapat diangsur, terjangkau, dan tetap maka akan dapat mendorong hasrat masyarakat untuk melanjutkan pendidikan ke jenjang yang lebih tinggi.

Hasil penelitian ini memperkuat temuan sebelumnya (Setyowati, 2015); (Kamila, 2018) dimana dengan biaya yang murah maka masyarakat akan tergerak untuk kuliah. Biaya kuliah yang fleksible membuat konsumen tanpa berpikir panjang untuk studi lanjut.

\section{Kepercayaan terhadap minat kuliah}

Kepercayaan pada penelitian ini tidak mempengaruhi minat kuliah. citra positif, kualitas pendidikan yang tidak terjaga, membuat konsumen tidak percaya sehingga konsumen tidak memiliki hasrat untuk studi lanjut.

Hasil temuan ini tidak sependapat dengan penelitian (Tilaar, Lapian, \& Roring, 2018); (Marwani \& Maulana, 2021) dimana tingkat kepercayaan yang meningkat akan ketertarikan untuk melanjutkan kuliah, namun apabila konsumen kurang percaya maka minat kuliah menurun. Hal ini dapat terjadi karena tidak semua konsumen memiliki persepsi yang sama.

\section{Intensitas promosi terhadap kepercayaan dan minat kuliah}

Intensitas promosi melalui kepercayaan dalam penelitian ini tidak mempengaruhi minat kuliah. Intensitas promosi yang dilakukan membuat konsumen percaya namun belum mampu meningkatkan minat kuliah.

Hasil penelitian ini memiliki kesamaan dengan sebelumnya (Kamila, 
2018) intensitas promosi tidak memiliki pengaruh terhadap minat kuliah. Kepercayaan tidak serta merta jadi penghubung intensitas promosi dan minat kuliah.

\section{KESIMPULAN}

$\begin{array}{ccc}\text { Hasil penelitian } & \text { dengan } \\ \text { menambahkan } & \text { variabel intervening }\end{array}$ kepercayaan tidak dapat mempengaruhi hubungan antara intensitas promosi dan minat kuliah. Namun intensitas promosi berpengaurh positif signifikan pada kepercayaan, serta biaya kuliah memiliki pengaruh pada minat kuliah.

Penelitian memberikan peluang penelitian selanjutnya berkenaan dengan intensitas promosi dan minat kuliah. serta penelitian selanjutnya dapat menggunakan variabel yang lebih spesifik menambahkan atau mengganti variabel penghubung selain kepercayaan.

\section{DAFTAR PUSTAKA}

Berlinasari, M., \& Erawati, N. M. (2017). PENGARUH MOTIVASI, BIAYA PENDIDIKAN DAN LAMA PENDIDIKAN PADA MINAT MAHASISWA AKUNTANSI MENGIKUTI PPAK. E-Jurnal Akuntansi Universitas Udayana, 447-476.

Fajarsari, H. (2020). Pengaruh Motivasi dan Persepsi Terhadap Minat Mahasiswa Mengikuti Pendidikan Profesi Akuntansi (PPAK) di Kota Semarang. Jurnal Pamator, 30-43.

Huang, i., Brink, H. M., \& Groot, W. (2011). College Education and Social Trust: An EvidenceBased Study on the Causal Mechanisms. Soc Indic Res, 287-310.

Kamila, F. (2018). PENGARUH PROMOSI, MOTIVASI DAN HARGA TERHADAP MINAT KULIAH PROGRAM PASCA SARJANA SEKOLAH TINGGI ILMU EKONOMI INDONESIA (STEI). Jurnal Akuntansi dan Manajemen,, 1-12.

Marwani, \& Maulana, A. (2021). PENGARUH MEDIA SOSIAL DAN KEPERCAYAAN TERHADAP MINAT BELI SEPATU VANS (STUDI PADA MAHASISWA FAKULTAS EKONOMI UNIVERSITAS SINGAPERBANGSA KARAWANG). Jurnal Ilmiah Mahasiswa Ekonomi Manajemen, 605-619.

Setyowati, T. (2015). ANALISIS SERVICE QUALITY, PROMOTION, COST STUDY DAN IMAGE DAMPAKNYA PADA MINAT KULIAH DI PERGURUAN TINGGI. Jurnal Manajemen Dan Bisnis Indonesia, 177-194.

Syaifulloh, M., Wahana, A. N., \& Riono, S. B. (2020). IMBAS BIAYA PENDIDIKAN TERHADAP MINAT STUDI LANJUT DI PERGURUAN TINGGI KABUPATEN BREBES. Syntax Idea, 92-98 .

Tilaar, F., Lapian, S. J., \& Roring, F. (2018). PENGARUH KEPERCAYAAN, DAN MOTIVASI TERHADAP MINAT BELI PENGGUNA SHOPPE SECARA ONLINE PADA ANGGOTA PEMUDA GMIM ZAITUN MAHAKERET. Jurnal EMBA, 2028 - 2037.

Wahyono, S. A., \& Susilawati. (2016). PENGARUH BAURAN PROMOSI TERHADAP KEPERCAYAAN DAN DAMPAKNYA TERHADAP KEPUTUSAN MAHASISWA MEMILIH KULIAH (Studi Kasus Politeknik LPKIA Kota Bandung). JURNAL INDONESIA MEMBANGUN, No. 2 Vol. 15 hal. 82-100.

Walno. (2019). Hubungan antara kepercayaan diri dan dukungan orang tua dengan minat melanjutkan studi ke perguruan tinggi. Prosiding Seminar Nasional Magister Psikologi Universitas Ahmad Dahlan, 335-340.

Wijayanto, T., Rahadhini, M. D., \& Sumaryanto. (2018). ANALISIS PENGARUH PROMOSI TERHADAP LOYALITAS KONSUMEN DENGAN KEPERCAYAAN SEBAGAI VARIABEL MEDIASI. Jurnal Ekonomi dan Kewirausahaan, 370-378 . 